\title{
India-ASEAN Cooperation in the Evolving Regional Mechanisms
}

\author{
Dr M Prayaga*
}

\begin{abstract}
The Association of Southeast Asian Nations (ASEAN) has been a flourishing regional organisation based on its core principles of dialogue and consensus, respect for sovereignty, equality, and non-interference. Whilst the collapse of the Soviet Union regime marked the end of the Cold war, the United States withdrawal from the Subic Bay and Clark Air Base in the Philippines in the 1990s, exacerbated ASEAN's sense of vulnerability in the post-Cold War security order. The ASEAN countries became skeptical about the regional security after the exit of two super powers. Further, China's rising economic powerhouse and military prowess at the next door caused concerns to the small and big countries in the region. Thus, the end of the Cold War certainly renewed the rise of regionalism and regional security institutions throughout the world. In the absence of major regional security institutions, except the Five Power Defence Arrangement (FPDA), ASEAN envisaged to found multilateral organizations to manage security and reduce tension in the region. The founders of the postwar security system, at large, acknowledged the multilateral mechanisms are desirable for economic cooperation, social coherence as well as to establish peace and stability in the region. ASEAN strongly believed that in the place of bilateral frameworks the establishment of multilateral mechanisms would provide a suitable platform to cater to the needs of political, economic and security cooperation among states in the Asia-Pacific region.
\end{abstract}

Keywords: India-ASEAN Cooperation, Post-Cold War era, Regional multilateral mechanisms, Regional security cooperation, ARF, EAS, ADMM-Plus, Major Powers, China and Asia-Pacific.

*Dr M Prayaga is an Assistant Professor at Centre for Southeast Asian \& Pacific Studies, S.V. University, Tirupati, India. 


\section{India-ASEAN Cooperation in the Evolving Regional Mechanisms}

\section{In Pursuit of Regional Institutions}

Southeast Asian region experienced conventional turbulence due to the escalation of land and maritime disputes in the region. Concomitantly, non-traditional challenges such as climate change, food and water security, natural disasters, smuggling, piracy, drug trafficking, cyberattacks and transnational crimes have emerged. These are non-military in nature; transnational in scope; spread rapidly and caused a lot of destruction (Nguyen \& Nguyen, 2019). Therefore, no country could deal singularly these threats efficiently. Addressing these types of challenges required closer coordination and multilateral cooperation amongst states, as well as between states and non-state actors. In this direction, ASEAN's most important contribution was the mainstreaming of nontraditional security challenges as a common agenda for regional cooperation, not only amongst member states but also involving the major powers in this endeavor (Baviera, 2017). In order to mitigate non-traditional threats, the role of defence cooperation has become more imperative to promote regional peace and stability. Southeast Asian countries firmly believed the region's security is best maintained through joint efforts by engaging the major powers in multilateral frameworks (Nathan, 1997). Hence, the stage was set for the creation of such multilateral institutions in the region and a beginning was made in this direction by launching ASEAN Regional Forum (ARF). Eventually, the launch of ARF gave scope to the foundation of ASEAN enabled cooperative mechanisms like, East Asia Summit (EAS), ASEAN Defense Ministers Meeting Plus (ADMM-Plus), Expanded ASEAN Maritime Forum (EAMF), ASEAN Dialogue Partners and ASEAN Community.

Big powers such as the US, Russia, China and reasonably influential players like India, Japan, South Korea, Australia and New Zealand evinced much interest to partner ASEAN in the evolving regional mechanisms. As a result, the US, China and Russia became participants in several regional multilateral cooperation mechanisms such as ARF, EAS and ADMM-Plus. This new approach, called "strategic engagement" sought to reduce potential conflicts and confrontation (Nguyen \& Nguyen, 2019). While involving themselves in the ASEAN-led mechanisms, major powers had adopted their own perceptions. The goals of the US engagement in regional institutions were: 
Establish and strengthen rules and norms as the foundation for solving regional problems; improve relations with the countries of Southeast Asia; bring China into this collaborative, rules-driven process of tackling shared challenges; and ensure that the United States is a part of regional discussions of key security issues to protect its interests (The White House, 2015).

With the rise of robust Chinese military, the 'Indo-Pacific' region assumed greater geopolitical significance particularly in the South China Sea (SCS). Hence, the US administration paid considerable attention through 'Pivot Asia', a diplomatic strategy, to reengage itself in the 'Indo-Pacific' construct. The US aims to employ regional institutions as a means to "work with China constructively in the region while also blunting the assertive, worrying aspects of China's regional policies, such as its drive to establish de facto control over disputed areas of the South China Sea" (Fuchs \& Harding, 2016). The US also intended to join regional mechanisms to find more areas of tangible cooperation in the multilateral context.

On the other hand, China has its own priorities and designs to work together and collaborate with ASEAN-led mechanisms on the issues of common impact. As reported by CSIS, China welcomed and supported 'ASEAN Centrality' in regional cooperation. In addition to bilateral relations, Beijing focused on multilateral defense cooperation with a view to enhance defense networking with ASEAN states which 'will help facilitate, not destabilize, regional peace and multi-polarity.' On China's engagement, its former defense minister Chang Wanquan stated: "China is ready to take concerted efforts with all ASEAN parties to actively utilize the existing security mechanisms, strengthen communication and synergy and jointly promote the building of new regional security cooperation architecture with Asian characteristics" (Tao, 2015). Thus, major powers displayed huge interest to work in tandem with ASEAN frameworks for their multiple regional benefits.

\section{ASEAN Regional Forum (ARF)}

The ARF, a high-profile grouping, which meets annually to discuss security issues of the Asia Pacific region, after constructive conclaves among its member states at the foreign minister level, dialogue partners and observers, got originated in July 1994. The capricious security milieu in Asia, particularly after the end of the Cold War, had provided ample weight to 
ASEAN to deliberate with different regional players and global powers on traditional and nontraditional challenges for establishing durable peace in the region. On the swift developments in the region, John Naisbitt, in his book Megatrends Asia, remarked, "Old Asia was divided by culture, language, political ideology, religious philosophies and geography. The new Asia, forged by economic integration, technology, especially telecommunications, travel and mobility of people, will increasingly look like one coherent region" (Smith, 1997). In this backdrop, ASEAN with an aim to build a multilateral security dialogue established ARF as the first wide security dialogue forum in Asia-Pacific. It applied 'ASEAN Way' by extending requisite norms and practices to this new multilateral cooperation. One salient feature is, it could accommodate the US, China, Russia, India and Japan, as well as cater to the needs of middle and smaller countries in concerns of common interest.

The formation of ARF was a milestone in the ASEAN development process. The ASEAN leaders declared "ASEAN shall move towards a higher plane of political and economic cooperation to secure regional peace and prosperity" (ASEAN, 1998). The chief objective of the ARF is mainly to seek resolution of conflicts through regional consensus and persuasion. Thus, the ARF has evolved into an important platform to discuss security issues and develop cooperation procedures to establish stability in the Indo-Pacific region. At present, the ARF comprises 27 members. The ARF chiefly discusses ideas and build confidence among member states to the promotion of regional peace and stability through three important stages: a) promotion of Confidence Building Measures; b) Development of Preventive Diplomacy Mechanisms; and c) Development of Conflict Resolution Mechanisms (Severino, 2009, pp. 142-145). The ARF facilitates regular consultations after ASEAN Ministerial Meetings at the level of senior officials, leaders of state and amongst academics, intellectuals and other members of the non-government organizations at three levels. On the contribution of ARF, Anthony Milner and Ron Huisken (Milner \& Huisken, 2019), CSCAP Australian Committee Members, said:

Although stressing the vastness of East Asia, and the many unresolved issues, including territorial disputes and weak traditions of addressing problems collectively, it expressed confidence that the ARF could move beyond the building of trust and confidence and begin averting conflicts. 
The recent Ministerial Meeting of the ARF held in Bangkok on 2 August 2019 focused on key regional issues including the Korean Peninsula, South China Sea, Counter-Terrorism and Cyber Security. At the meeting, Ministers adopted a joint proposal of Australia and Malaysia to establish an 'ARF Points of Contact Directory on Security' so as to avail the Information and Communications Technologies to facilitate the sharing of information in the event of potential cyber security incidents (ARF, 2019). The ARF has been functioning by convergence of political, security and social issues to attain solidarity in the multilateral mechanisms.

\section{India-ARF Partnership}

The refashioned foreign policy, geographical proximity and multifaceted cooperation turned India as ASEAN's natural partner. Consequently, India was given priority in many engagements across political, economic and security activities of ASEAN-led forums like ARF, EAS and ADMM-Plus.

India, after becoming Dialogue Partner of ASEAN in 1995, took several steps and turned itself a close associate in ASEAN-led regional mechanisms. ASEAN, which intended to help protect regional interests, invited India to join ARF while New Delhi made its maiden presence as member in Jakarta in July 1996. India's inclusion in the ARF was hailed as a major diplomatic achievement and logical extension of its Look East Policy (LEP). ARF's admission helped India not only to play its benign role in promoting peace and stability in the region but also so secure a place on par with the global powers in regional security affairs. These diplomatic maneuvers marked a dramatic reversal of Indian policy, which had previously been strongly opposed to participating in multilateral security fora (Ladwig, 2009). Though Pokhran-II nuclear tests in 1998 bore the brunt of the US and its allies, who threatened to impose sanctions, the members of the ARF were sympathetic towards New Delhi in the context of the lingering Indo-Pakistani conflicts. Thus, the ARF acted as a catalyst to lessen the tensions and promote peace in Asia-Pacific region. India too became conscious of its obligation to help achieve the ARF's key goals and to abide by the resolutions of the ARF. Further, a decade later, the Mumbai terrorist attacks in November 2008 were condemned unequivocally by the foreign ministers of the ARF. In the wake of this horrifying act, the ARF focused on expanding intraregional cooperation in combating terrorism in the region. India, a long-time victim of terrorism, made a strong point for sharpened focus on uniting ARF countries to fight against 
terrorism either individually or collectively. So as to foster greater cooperation in the vital area of security, India organized several seminars, workshops and training programmes such as United Nations Peacekeeping course in Delhi; Maritime security training course in Chennai and Anti-piracy training by Indian Coast Guard in Mumbai for ARF members (ARF, 2012).

India also worked for the peaceful resolution of critical South China Sea (SCS) issue. At the ARF meeting (2014) the then External Affairs Minister Sushma Swaraj affirmed India's commitment to the peaceful resolution of disputes and freedom of navigation in the region. It clearly exhibited India's willingness to accommodate ASEAN stakeholders' viewpoints to the complexities of the disputes in the SCS. The Chairman's Statement, at the $16^{\text {th }}$ India-ASEAN Summit held in Bangkok on 3 November 2019, emphasized that both parties agreed to continue to utilise ASEAN-led mechanisms so effectively in response to growing traditional and nontraditional security challenges. They also "reaffirmed the importance of maintaining and promoting peace, security, stability, safety and freedom of navigation in and over flight above the South China Sea, and recognised the benefits of having the South China Sea as a sea of peace, stability and prosperity" (ASEAN, 2019). Thus, India's role in ASEAN-led regional mechanisms is just too important to ignore.

However, some critics, while dubbing the ARF as a "talk shop" pointed out that the ARF has been unsuccessful because of its unwieldy number of 27 member states. On the contrary, strategic analysts, Milner and Huisken (Milner \& Huisken, 2019) highlighted the positive role being played by the ARF:

The United States, China, Japan and India might be frustrated at times by ASEAN diplomacy but they have all declared support for this ASEAN centrality. Not only does it help avoid a more direct contest between these larger states, but the Southeast Asian leaderships have demonstrated a talent for maintaining "equidistance" between contending powers.

\section{Role of East Asia Summit in regional affairs}

The ASEAN instituted East Asian Summit (EAS) in 2005 to engage more countries for strategic dialogue and cooperation in political, social and economic issues of common concern 
of the region as well as to build it as an important forum in the 'Indo-Pacific' security architecture. The concept of an 'East Asia Grouping', which includes Southeast Asia and East Asia, was first initiated in 1991 by the then Malaysian Prime Minister, Mahathir bin Mohamad. In 2005, Gloria Arroyo, President of the Philippines, called upon the ASEAN to "embrace China, Japan, South Korea and India" in a larger grouping which will be in a better position to "hold its own" while negotiating with the US or the European Union (Sinha \& Mohta, 2007). Though initially reluctant, the US showed huge interest to join the group to maintain access to the Indian Ocean and also serve as a counterweight to China. Both the United States and Russia have lobbied hard to join the summit in 2011, which was a proof of the forum's perceived potential. At present, EAS comprises 18 members -10 ASEAN members plus China, Japan, South Korea, India, Australia, New Zealand, the US and Russia. It was a testimony to the growing influence of the EAS, which represents nearly 54 per cent of the world's population and accounts for 58 per cent of global GDP (EAF, 2019). The EAS is an exclusive 'leaders led' forum for dialogue on broad strategic, geopolitical and economic issues of mutual interest and to engender peace, security, stability and economic prosperity in the region (AIC, 2020). The cooperation between ASEAN and its EAS partners encompasses physical, institutional and people-to-people connectivity. Towards establishing a strong trade regime EAS countries launched the Regional Comprehensive Economic Partnership (RCEP), which includes India, in November 2012 (DFAT, n.d).

The EAS firmly believed that safety of the region would be ensured only through a 'balance of interests,' which was somewhat different from a 'balance of power'. Southeast Asian policymakers viewed China's expanding regional dominance as a possible security threat. In these circumstances, EAS was viewed as viable mechanism for its implications for regional trade and security. It was also crucial for its potential importance of challenging the US-China contention in the region.

Annual meetings of EAS were usually hosted in conjunction with the top-level events of the ASEAN alongside ASEAN Leaders' meeting in the last quarter of the year. The latest $14^{\text {th }}$ EAS was held in Bangkok, Thailand, on 4 November 2019. Various issues concerning economic cooperation, energy, food and responses to the serious challenges of climate change were discussed at EAS meeting. The EAS called for effective measures to counter terrorism, including containing terror financing in the region, which was seen as an affirmation of India's 
call for a concerted approach to deal with terror groups. It was also resolved to ensure effective implementation of Financial Action Task Force (FATF) standards to deal with terror financing. The EAS declaration affirmed, "it will deepen cooperation with the Financial Action Task Force (FATF), the United Nations Office on Drugs and Crime (UNODC)” (ET, 2019).

\section{India-EAS cooperation}

In fifteen years, the EAS has emerged as the leading forum for strategic dialogue in the 'IndoPacific' region. In 2005, India joined EAS as one of its founding members. On India's inclusion, PS Suryanarayana, columnist of Frontline magazine, pointed out, "Southeast Asia "re-discovered" India as an ancient cultural force with a new political relevance to Greater East Asia." He further said, "India's growing profile as a major maritime power of the military kind is of particular importance to ASEAN" (Suryanarayana, 2007). On New Delhi's admission into EAS, N. Jaishankar, former Foreign Secretary of India, acknowledged, "India was privileged to be one of its original members and this gathering is a key event in our annual diplomatic calendar" (MEA, 2017).

In the EAS meetings India addressed an array of issues ranging from freedom of navigation, nuclear crisis, and total ban on chemical weapons and for an end to International terrorism in the Indo-Pacific region. India also substantially contributed to discuss and debate various other subjects such as transnational crime, terrorist financing, illegal arms dealing and International Law. India also pointed out the growing tensions in the SCS, which would jeopardise international peace and argued that threats must be effectively tackled for the benefit of the national interests of claimant states in the region. India was successful in using the side-lines of the EAS meetings to resolve the long pending issues as well as strengthening of bilateral relations. Indian Prime Minister Manmohan Singh met his Australian counterpart Tony Abbott on the side-lines of the $8^{\text {th }}$ EAS held in October 2013 in Bandar Seri Begawan. The meeting helped India and Australia to take forward their negotiations to agree to a civilian nuclear cooperation agreement. In September 2014, the Prime Ministers of two countries eventually signed the agreement that enabled India to import Australian uranium. Confirming the agreement the Indian External Affairs Ministry (EAM) said, "Australia will now be a "longterm reliable supplier of uranium to India." The EAM further stated that the agreement would 
provide for the "supply of uranium, production of radio isotopes, nuclear safety and other areas of cooperation" (Haider, 2014).

Another important step in cultural ties between India and EAS was the reviving of Nalanda University in Rajgir, Bihar. Respecting the idea of reviving of the ancient Nalanda University mooted by the former President of India, A.P.J. Abdul Kalam, in March 2006, the EAS held in the Philippines in 2007 endorsed the proposal to re-establish Nalanda University. This regional initiative for the revival of Nalanda University, which was unanimously and enthusiastically welcomed, garnered greater support at the fourth EAS held in Thailand in October 2009, where its members affirmed the merit of establishing the Nalanda University and encouraged the idea of regional networking and collaboration between the University and existing centres of excellence in East Asia (Nalanda University, n.d). Subsequently, the prestigious project took off, with enactment of the Nalanda University Act 2010 in both the Houses of the Indian Parliament. The historic opening of the University started functioning from 2014.

India, as a responsible stakeholder of the EAS, hosted an 'EAS-India Workshop' in 2012 on Building Regional Framework for Earthquake Risk Management in New Delhi for the disaster prevention and management. At the $12^{\text {th }}$ EAS held in 2017, member countries discussed matters of regional and international interest and expressed concern for maritime security, terrorism, non-proliferation and irregular migration. At the same meeting Prime Minister Narendra Modi conveyed India's commitment to work with EAS, and said, "We look forward to the East Asia Summit attaining greater salience in years to come. I reiterate my commitment to work with you to address the political, security and economic issues of the region" (PTI, 2017). The forum's conducive climate made Narendra Modi, at the EAS Summit held in Bangkok in November 2019, to propose a new initiative called the "Indo-Pacific Oceans Initiative," which was a reiteration of India's commitment towards a free, open and inclusive Indo-Pacific region based on a rules-based order. It drew the attention of the members for "creating partnerships among interested States in several pillars ranging from enhancing maritime security to preserving and sustainably using marine resources, building capacity, disaster prevention and management as well as working together in trade and maritime transport" (MEA, 2019). However, this initiative was viewed by experts as the "focus on the strategic maritime space in the Indo-Pacific' and "also as a clear indicator of India's willingness to address China's maritime aggressiveness in an emphatic manner" (Rajagopalan, 2019). In 
addition, India strongly believed that there is a lot of scope for broader regional engagement among EAS members in the spheres of collective capacity for disaster relief and rescue and energy security, food security and connectivity.

\section{ASEAN Defence Ministers' Meeting Plus (ADMM-Plus)}

The ASEAN Defence Ministers' Meeting (ADMM) was founded in 2006. At the $2^{\text {nd }}$ ADMM held in Singapore in 2007, it adopted a resolution to establish the ASEAN Defence Ministers' Meeting Plus (ADMM-Plus). The ADMM-Plus, a platform comprising ASEAN countries and its eight partners (Australia, China, India, Japan, New Zealand, Russia, South Korea and the United States), was commissioned in Hanoi in 2010 (ASEAN, n.d). The ADMM-Plus is the highest defense consultative and cooperative mechanism in the Asia-Pacific region. The defense ministers of the ADMM-Plus agreed on seven areas of cooperation, including maritime security, counter-terrorism, humanitarian assistance and disaster management, peacekeeping operations, military medicine, humanitarian mine action and cyber security. Experts Working Groups (EWGs) have been established to facilitate cooperation on above areas among members (ADMM, 2017). ADMM-Plus aims to promote mutual trust and confidence through greater understanding of defense cooperation for peace, stability, and development of the region. This group enables ASEAN members to interact with major powers and provides a high-level venue to discuss transnational defense-security cooperation. In a relatively short span of time the ADMM-Plus has had a remarkable niche in advancing multilateral cooperation through strategic dialogue and practical security cooperation. In its annual meetings, the member countries proposed to increase joint efforts in promoting practical cooperation and collaboration on maritime security as well as to the peaceful resolution of disputes without resorting to the threat or use of force. The statement of the $4^{\text {th }}$ ADMM-Plus held in October 2017 said (MoD, 2017):

In a short span of time, the ADMM-Plus has emerged as a credible and effective platform which has forged practical co-operation among the armed forces of member countries in key areas. In doing so, we have been guided by the principles of consensus, transparency and mutual respect for each other's priorities and sensitivities. 
This ASEAN-centered security forum, together with the defense ministers is working for promoting an open, inclusive, and rules-based regional order. On the significance of ADMMPlus in offering a joint platform for the large and smaller countries, Amy Searight, an American strategic analyst opined, the "strategic dialogue, confidence-building measures, and multilateral exercises are all valuable tools to promote regional stability...." (Searight, 2018).

\section{India in ADMM-Plus maneuvers}

India did engage ADMM-Plus defense ministers and officials in multilateral consultations to strengthen regional security. While addressing the $4^{\text {th }}$ ADMM-Plus, Indian defense minister called for safeguarding freedom of navigation which is a key concern of East Asian states. He also expressed concern about the escalation of tension in the Korean Peninsula and called for peaceful conflict resolution through diplomatic means (MoD, 2017). One of the shining examples of the joint cooperation was the "Force 18" combined "Field Training Exercise on Humanitarian Mine Action and Peace Keeping Operations' organized in Pune in 2016. The maiden multinational exercise ever conducted by ground forces on Indian soil witnessed participation of 18 ASEAN Plus nations including China, USA, Russia, Japan and South Korea. The spirit of the exercise 'was to learn and share the best practices with the other Armies of the world' and display their commitment for peace and stability in the region (Anand, 2016). Besides, India regularly took part in ADMM-Plus counterterrorism drills. Naval ship 'Airavat' participation in the 2018 drills certainly bolstered India's ties with all the participating navies.

While describing South China Sea as a major waterway through which over US\$ 5 trillion worth of trade passes, including 55 per cent of Indian trade, Rajnath Singh, Indian Defense Minister who attended the $6^{\text {th }}$ ADMM-Plus edition, explained, "India's Indo-Pacific vision is based on the idea of sustainable security as it focuses on a free, open, inclusive and rules based Indo-Pacific; one in which there is respect for sovereignty and territorial integrity of everyone involved." He also urged ADMM-Plus members to eliminate terrorist havens, disrupt their networks and financing and thwart their movement to ensure regional security (Singh, 2019).

The Chairman's statement released at the $16^{\text {th }}$ India-ASEAN summit on November 2019 in Bangkok stated: "We agreed to continue utilizing these mechanisms to effectively respond to 
traditional and non-traditional security challenges" (ASEAN, 2019). Reciprocating India's involvement and contribution, ASEAN countries eulogized New Delhi's affirmative participation in ASEAN-led mechanisms, including the ARF, EAS and ADMM-Plus.

\section{Conclusion}

The dawn of the $21^{\text {st }}$ century started experiencing further surge of great power politics, militarization, transnational crimes, piracy, climate change, food and energy security and endemic diseases at global level. The challenges like freedom of navigation and over flight and maritime security and international law are added to the woes. In order to tackle all these challenges and to ensure stability and prosperity throughout the world partnerships and multilateral cooperation is the solitary way. ASEAN known for solidarity and unity gradually established regional mechanisms such as ARF, EAS and ADMM-Plus to address conventional and non-conventional threats in the 'Indo-Pacific' region.

ASEAN-led regional mechanisms exhibited greater sensitivity and balance to security concerns of the Indo-Pacific region and swelling challenges in the South China Sea, as well. There are huge spillover effects on the region with the ostensible economic growth and military might of China. The stability of the region was shattered by a series of antagonistic Chinese actions and the US enthusiastic deeds. In order to avoid instability that may emerge out of China's dominance in this geopolitical region, ASEAN tried to establish peace and stability by dovetailing major powers into the regional security mechanisms. ASEAN's multilateral diplomacy, through Confidence Building Measures and conflict resolving mechanisms, has been offering certain openness and more engagement with other regional powers. The conclaves of the ASEAN-centered frameworks were proved to be an effective means for reinforcing problem-solving process in due course. However, the multilateral forums' deliberations are not a panacea, they permit debate on the diverse issues of political, economic cooperation as well as collaboration in humanitarian and security issues of common interest for region's continued prosperity and stability.

India's regional engagement is strengthened by its broad range of multilateral economic, political, defense and security relationships with all the members of ASEAN. India's unreserved multi-level cooperation in ARF, EAS and ADMM-Plus groupings (ASEAN's 
famous 'Trio') proved worthy in the fast changing geopolitics of the Indo-Pacific region. As well, India's benign engagement in ASEAN-led mechanisms would weaken the actors who dream of benefit from divergences in the region. On this firm foundation, the ASEAN-centered mechanisms together with major powers should unleash numerous opportunities to their potential for establishing rules-based order as well as durable growth and stability in the IndoPacific region.

\section{References}

Nguyen, H.Q., \& Nguyen, V.K. (2019, April-June). Multilateral Mechanisms in the AsiaPacific Region: Impact on ASEAN's Centrality and Implications for Vietnam. (USI) Retrieved May 01, 2020, from https://usiofindia.org/publication/usi-journal/multilateral-mechanisms-inthe-asia-pacific-region-impact-on-aseans-centrality-and-implications-for-vietnam/.

Baviera, A. (2017). Preventing War, Building a Rules-based Order: Challenges Facing the ASEAN Political-Security Community. (ERIA) Retrieved December 20, 2019, from https://www.eria.org/ ASEAN_at_50_4A.0_Baviera_final.pdf.

Nathan, K.S. (1997). ASEAN and the major powers: Adjusting to new power realities towards the 21st century. Asian Journal of Political Science, 5:1, Pp 102-106.

Nguyen, H.Q., \& Nguyen, V.K. (2019, April-June). Multilateral Mechanisms in the AsiaPacific Region: Impact on ASEAN's Centrality and Implications for Vietnam. (USI) Retrieved May 01, 2020, from https://usiofindia.org/publication/usi-journal/multilateral-mechanisms-inthe-asia-pacific-region-impact-on-aseans-centrality-and-implications-for-vietnam/.

The White House. (2015, November). Fact Sheet: U.S-ASEAN Relations. (Whitehouse) Retrieved April 16, 2020 from https://www.whitehouse.gov/the-press-office/2015/11/21/ factsheet-us-asean-relations

Fuchs, M. H. \& Harding, B. (2016, May). The Missing Link: Multilateral Institutions in Asia and Regional Security, (CDN) Retrieved March 20, 2020, from https://cdn.americanprogress.org/wp-content/uploads/2016/05/27091406/AsianRegional Architecture-report.pdf.

Tao, H. (2015, March). From Bilateralism to Multilateralism: Evolution and Prospects of ASEAN Defense Cooperation. (CIIS) Retrieved April 03, 2020, from http://www.ciis.org.cn/english/2015-03/10/content_7733810.htm.

Smith, G.J. (1997). Multilateralism and Regional Security in Asia: The ASEAN Regional Forum (ARF) and APEC's Geopolitical Value. (WCFIA) Retrieved March 22, 2020, from https://wcfia.harvard.edu/publications/multilateralism-and-regional-security-asia-aseanregional-forum-arf-and-apecs. 
ASEAN Secretariat. (1998). ASEAN at 30. Jakarta. P 44.

Severino, R.C. (2009). The ASEAN Regional Forum. Singapore: Institute of Southeast Asian Studies. Pp 142-145.

Milner, A. \& Huisken, R. (2019, March). ASEAN Regional Forum: less might be more. (LOWY) Retrieved May 2, 2020, from https://www.lowyinstitute.org/the-interpreter/aseanregional-forum-less-might-be-more.

ASEAN Regional Forum (ARF). (2019, September). (DFAT) Retrieved March 04, 2020, from https://www.dfat.gov.au/international-relations/regional-architecture/Pages/asean-regionalforum-arf.

Ladwig III, W.C. (2009). Delhi's Pacific Ambition: Naval Power, "Look East," and India's Emerging Influence in the Asia-Pacific. Asian Security. 5: 2. P 94.

ASEAN Regional Forum (ARF). (2012, August). (MEA) Retrieved March 25, 2020, from https://www.mea.gov.in/Portal/Foreign Relation/ asean-regional-forum-august-2012.pdf.

Chairman's Statement of the 16th ASEAN-India Summit Bangkok/Nonthaburi. (2019, November). (ASEAN) Retrieve April 20, 2020, from https://asean.org/storage/ 2019/11/13400_FINAL-Chairmans-Statement-of-the-16th-ASEAN-India-Summit.pdf.

Milner, A. \& Huisken, R. (2019, March). ASEAN Regional Forum: less might be more. (LOWY) Retrieved May 2, 2020, from https://www.lowyinstitute.org/the-interpreter/aseanregional-forum-less-might-be-more.

Sinha, A. \& Mohta, M., (Eds.). (2007). Indian Foreign Policy: Challenges and Opportunities. New Delhi. Pp 420-421.

EAF (04 November, 2019). Straining to achieve potential at the East Asian Summit in Bangkok, Retrieved 09 April 2020, from: https://www.eastasiaforum.org/2019/11/04/straining-toachieve-potential-at-the-east-asian-summit-in-bangkok/

AIC (07 August 2020). India and the ASEAN: A Pivotal Relationship. Retrieved on 11 August 2020, from: http://aic.ris.org.in/india-and-asean-pivotal-relationship

DFAT (n.d). Regional Comprehensive Economic Partnership, Retrieved 11 April 2020 from: https://www.dfat.gov.au/trade/agreements/negotiations/rcep

The Economic Times (November 4, 2019). East Asia Summit vows to step up anti-terror cooperation...

Suryanarayana, P.S. (2007, May). Tyranny of the timid. Frontline, 24:9.

MEA (2017). India, ASEAN and Changing Geopolitics. Retrieved March 18, 2020 from https://mea.gov.in/Speeches-Statements.htm?dtl/28609/Speech_by

Dr_S_Jaishankar_Foreign_Secretary_to_mark_25_years_of_IndiaSingapore_Partnership_at_ Shangri_La_Hotel_Singapore_July_11_2017. 
Haider, S. (September 5, 2014). India, Australia seal civil nuclear deal. The Hindu.

Nalanda University:History and Revival. Retrieved April 5, 2020 from https://nalandauniv.edu.in/about-nalanda/ history-and-revival/.

PTI (14 November, 2017). PM Narendra Modi conveys India's commitment to work with East Asia Summit, The Economic Times. Retrieved from: https://economictimes.indiatimes.com/news/politics-and-nation/pm-narendra-modi-conveysindias-commitment-to-work-with-east-asiasummit/articleshow/61642755.cms?utm_source=contentofinterest\&utm_medium=text\&utm_ campaign $=$ cppst

MEA (04 November, 2019). Transcript of Media Briefing by Secretary (East) during PM's visit to Thailand (November 04, 2019). Retrieved from: https://mea.gov.in/mediabriefings.htm?dtl/32007/Transcript_of_Media_Briefing_by_Secretary_East_during_PMs_vis it_to_Thailand_November_04_2019

Rajagopalan, R.P. (2019, November). India's must look beyond ASEAN in regional security. (ORF) Retrieved March 15, 2020, from https://www.orfonline.org/ research/indias-must-lookbeyond-asean-in-regional-security-57417/.

ASEAN (n.d). ASEAN Defence Ministers Meeting (ADMM). Retrieved from: https://asean.org/asean-political-security-community/asean-defence-ministers-meeting$\mathrm{admm} /$

ADMM (06 February, 2017). About the ASEAN Defence Ministers' Meeting Plus (ADMMPlus). Retrieved from: https://admm.asean.org/index.php/about-admm/about-admm-plus.html.

MoD (November, 2017). RM's Statement at 4th ASEAN Defence Ministers' Meeting Plus (Admm Plus). https://mod.gov.in/sites/default/files/RMADMM.pdf.

Searight, A. (2018, November). ADMM-Plus: The Promise and Pitfalls of an ASEAN-led Security Forum. (CSIS) Retrieved April 26, 2020, from https://www.csis.org/analysis/admmplus-promise-and-pitfalls-asean-led-security-forum

MoD (November, 2017). RM's Statement At 4th ASEAN Defence Ministers' Meeting Plus (Admm Plus). https://mod.gov.in/sites/default/files/RMADMM.pdf.

Anand, R. (2016, March). “FORCE 18” India Hosts Multilateral Exercise. Retrieved April 26, 2020, from http://www. sainiksamachar.nic.in/englisharchives/2016/mar16-16/h5.htm.

Singh, M (19 November, 2019). India calls for demilitarisation of South China Sea. The New Indian Express, Nation, 19 November 2019. Retrieved from: https://www.newindianexpress.com/nation/2019/nov/19/india-calls-for-demilitarisation-ofsouth-china-sea-2063667.html

ASEAN (03 November, 2019). Chairman's Statement of the 16th ASEAN-India Summit Bangkok/Nonthaburi. Retrieved March 17, 2020, from https://asean.org/storage/ 2019/11/13400_FINAL-Chairmans-Statement -of-the-16th-ASEAN-India-Summit.pdf. 